\title{
A Society Coming out of Conflict: Reflecting on 20 Years of Recording Public Attitudes with the Northern Ireland Life and Times Survey Social and Behavioural Sciences
}

\author{
Paula Devine \\ ARK, Queen's University Belfast, U K \\ p.devine@qub.ac.uk \\ Gillian Robinson \\ ARK, Ulster University, U K \\ gm.robinson@ulster.ac.uk
}

\begin{abstract}
Annual public attitudes surveys are important tools for researchers, policy makers, academics, the media and the general public, as they allow us to track how - or if public attitudes change over time. This is particularly pertinent in a society coming out of conflict. This article highlights the background to the creation of the Northern Ireland Life and Times Survey in 1998, including its links to previous survey research. Given the political changes after the Good Friday/Belfast Agreement in 1998, the challenge was to create a new annual survey that recorded public attitudes over time to key social issues pertinent to Northern Ireland's social policy context. 2018 marks the 2oth anniversary of the survey's foundation, as well as the 2oth anniversary of the Agreement. Thus, it is timely to reflect on the survey's history and impact.
\end{abstract}

\section{Keywords}

Northern Ireland - public attitudes - attitudes survey - good relations - conflict

- Related dataset "Northern Ireland Life and Times Survey" with URL https:// discover.ukdataservice.ac.uk/series/?sn=2000040 in repository "UK Data Service".

(C) PAULA DEVINE AND GILLIAN ROBINSON, 2019 | DOI:10.1163/24523666-00401001

This is an open access article distributed under the terms of the prevailing CC-BY license at the time of publication. 
1. Introduction

Annual public attitudes surveys are important tools for researchers, policy makers, academics, the media and the general public, as they allow us to track how - or if - public attitudes change over time. Public attitudes reflect contemporary events, whilst at the same time, contemporary events reflect public attitudes. This article highlights the experience of the Northern Ireland Life and Times (NILT) Survey in recording public attitudes, and reflecting events, in a society coming out of conflict. Given that 2018 marks the $20^{\text {th }}$ anniversary of the survey's foundation, it is timely to reflect on its history and impact.

The conflict in Northern Ireland is highly contested. Whilst many perceive it to have begun during the latter half of the $20^{\text {th }}$ century, there have been centuries of conflict within Ireland, focusing on ethno-religious and national identity, constitutional preferences, and equality and power. For a useful exploration, see Hayes \& McAllister (2013). The most recent period of conflict beginning in the late 1960's is highly researched and documented. The most valuable online resources for political and legislative material are CAIN (Conflict Archive on the Internet), which can be accessed at www.ark.ac.uk/cain and Northern Ireland Elections, which provides a comprehensive set of election results at www.ark.ac.uk/elections.

Whilst election results provide some measure of public opinion, voting behaviour can often reflect more than personal affiliation. For example, someone may vote tactically against their preferred candidate in order that a third candidate is not elected. Thus, public opinion can be more extensively gauged using surveys. This is especially true in situations where to express personal opinions publicly may be dangerous. Survey data can help explain the motivations, or at least, the social and political context, of those carrying out the conflict (Hayes \& McAllister, 2013, p. xi), as well as those who are living within the conflict. Thus, there is a strong history of public attitudes research in Northern Ireland, including the Loyalty Survey undertaken by Richard Rose in 1968 (Rose, 1975) and the Northern Ireland Attitude Survey undertaken by Edward MoxonBrowne in 1978 (Moxon-Browne, 1983). While these were one-off surveys, the latter deliberately included many of the same questions included in the former, in order to make comparisons over time. The focus of these two studies was very clearly on politics and identity, and did not explore more social policy related themes. It goes without saying that the political context, and intercommunal violence in Northern Ireland resulted in difficult and dangerous working environments for research teams, and for interviewers in particular.

The Northern Ireland Social Attitudes (NISA) Survey was a repeated crosssectional survey running from 1989 to 1996 . Created to run parallel to the British Social Attitudes (BSA) Survey, the majority of questions within NISA were 


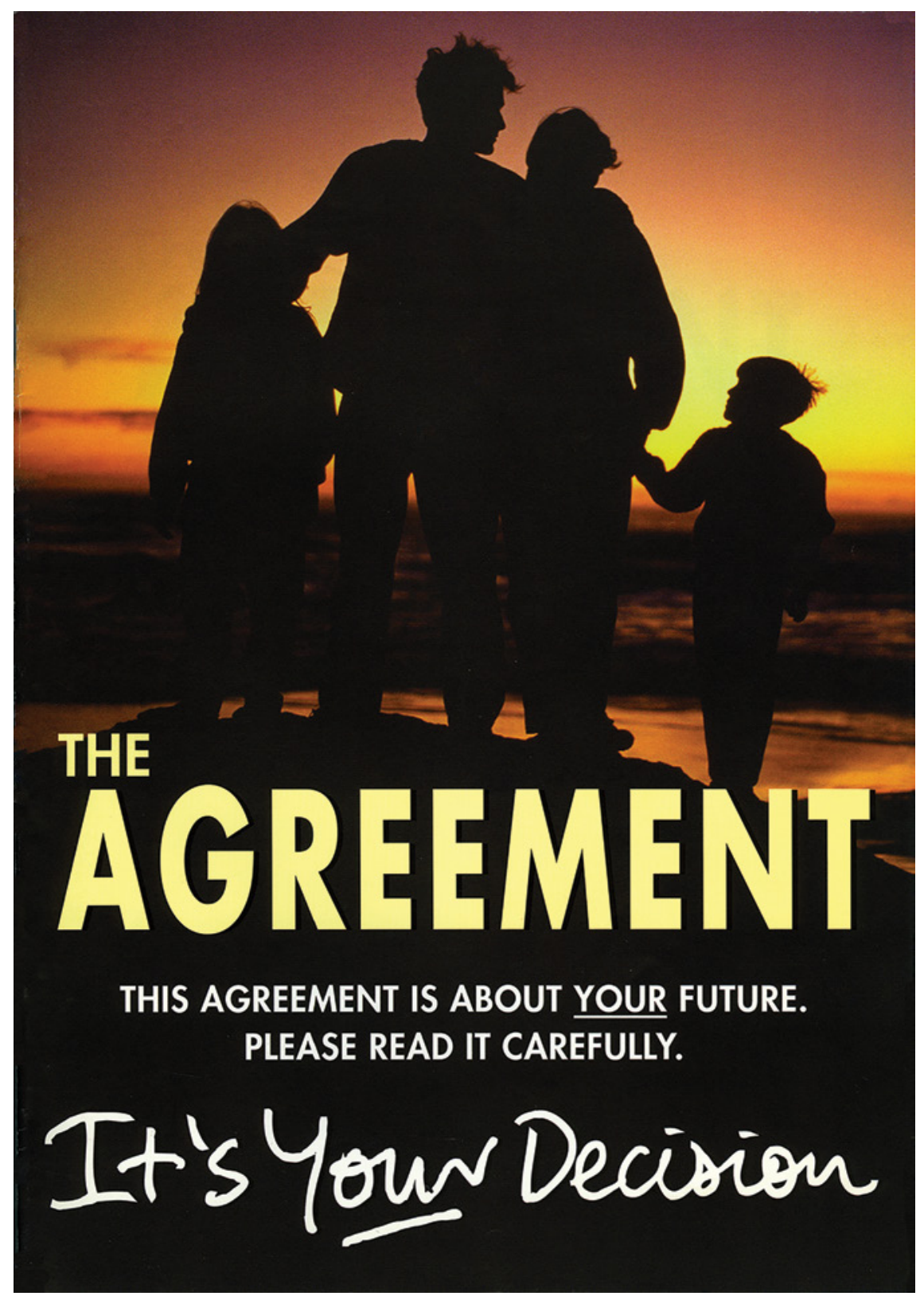

FIGURE 1 Front page of the Good Friday/Belfast Agreement

also asked within BSA, thus facilitating cross-national comparison. A short module on Northern Ireland-specific questions was also included within NISA, mostly focusing on community relations (relations between Protestant/Unionist/Loyalist and Catholic/Nationalist/Republican communities) and political 
attitudes. In general, however, NISA reflected the priorities of the BSA. Funding for NISA ended in 1996.

Around that time, the Peace Process in Northern Ireland was gaining momentum. Ceasefires began in 1994, and political negotiations culminated in the signing of the Good Friday or Belfast Agreement in 1998. (See Figure 1, the text of the Agreement is available on CAIN at http://cain.ulst.ac.uk/events/ peace/docs/agreement.htm). The Northern Ireland Act of 1998 allowed for the setting up of a legislative Assembly, and it was within this context that NILT was founded.

\section{The Challenge}

The aim of the Northern Ireland Life and Times survey was, and remains, the provision of publicly-accessible information on public attitudes to inform public and policy debate, as well as to provide a time series of public opinion. Under devolution, the Northern Ireland Assembly took control of social policy areas, including health, education and the economy. A fledgling lobbying culture was beginning to emerge at that time, aiming to influence the new political institutions. Independent and statistically-robust data and evidence was essential for this. Thus, the challenge was to create a new annual and independent survey that recorded public attitudes to major issues within Northern Ireland.

In order to provide an ongoing barometer of public opinion, it was important that this annual survey carried on the time series that began with NISA Despite its emphasis on Northern Ireland, the NILT team did not want to totally preclude cross-national comparisons. Thus questions relevant to other parts of the $\mathrm{UK}$, and further afield were included, for example, by participating in the International Social Survey Programme (ISSP). Within ISSP, the same module of questions is fielded in over 40 countries worldwide - for more information, see http://www.issp.org.

\section{3. $\quad$ Methods}

The first Northern Ireland Life and Times Survey was fielded in autumn 1998. The survey was designed with a modular format, with each module focusing on a specific topic to reflect current social and public debates. On an ongoing basis, each year's survey incorporates four or five modules, as well as a comprehensive background section recording socio-demographic and socioeconomic variables. 
The NILT sampling methodology was based on NISA, that is, a crosssectional survey based on two-stage random samples of adults aged 18 years or over living in private households. Firstly, a random sample is extracted from a household using a sampling frame such as the Postal Address File. Secondly, one adult of eligible age is randomly selected. This sampling methodology reflects the lack of a comprehensive individual-level sampling frame in Northern Ireland. From 1998 to 2004, the achieved sample size was 1,80o. Whilst this was reduced to 1,200 in order to reduce costs, this achieved sample size provided enough respondents for sub group analysis. The large sample size, along with the random sampling procedure, enabled the survey to provide a statistically-robust way of recording public attitudes. Comparisons of demographic characteristics with those from the Census of Population, and the Continuous Household Survey (a cross-sectional multi-topic government survey with a similar sampling methodology to NILT) indicate that the NILT samples are representative of the population in Northern Ireland (Devine, 2018).

\subsection{Exploring Equality and Identity in Northern Ireland}

When undertaking cross-national comparisons (for example, using ISsP data), it is imperative to use a standard set of analysis variables. However, this is not always possible, given the specific political context and the conflict in Northern Ireland. Two specific issues within Northern Ireland are identity and equality.

Section 75 of the Northern Ireland Act 1988 requires public authorities to promote equality of opportunity between nine equality categories: people of different religious belief, political opinion, racial group, age, marital status or sexual orientation, men and women generally, people with a disability and people without, and people with dependants and people without. The NILT team ensures that the survey captures details pertaining to these Section 75 groups.

Historically, the number of people from minority ethnic groups living in Northern Ireland has been small, perhaps reflecting the negative effect of the conflict on immigration. However, since the ceasefires in 1994, and the expansion of the European Union, the population living in Northern Ireland has become more diverse. Nevertheless, the number of people who describe themselves other than 'white' is very small, meaning that analysis and reporting based on ethnicity is not possible. For that reason, and in order to protect anonymity, an ethnicity variable is not included in the publicly-available dataset.

Recording national identity within a survey can be difficult, not least because we do not always understand the processes that shape it, nor is it set in stone (Bechhofer \& McCrone, 2010). Responses to a question on national identity are British/Irish/Ulster/Northern Irish/Other/Don't know. Between 1989 and 2017 , there has been a fall in the proportion of respondents saying 


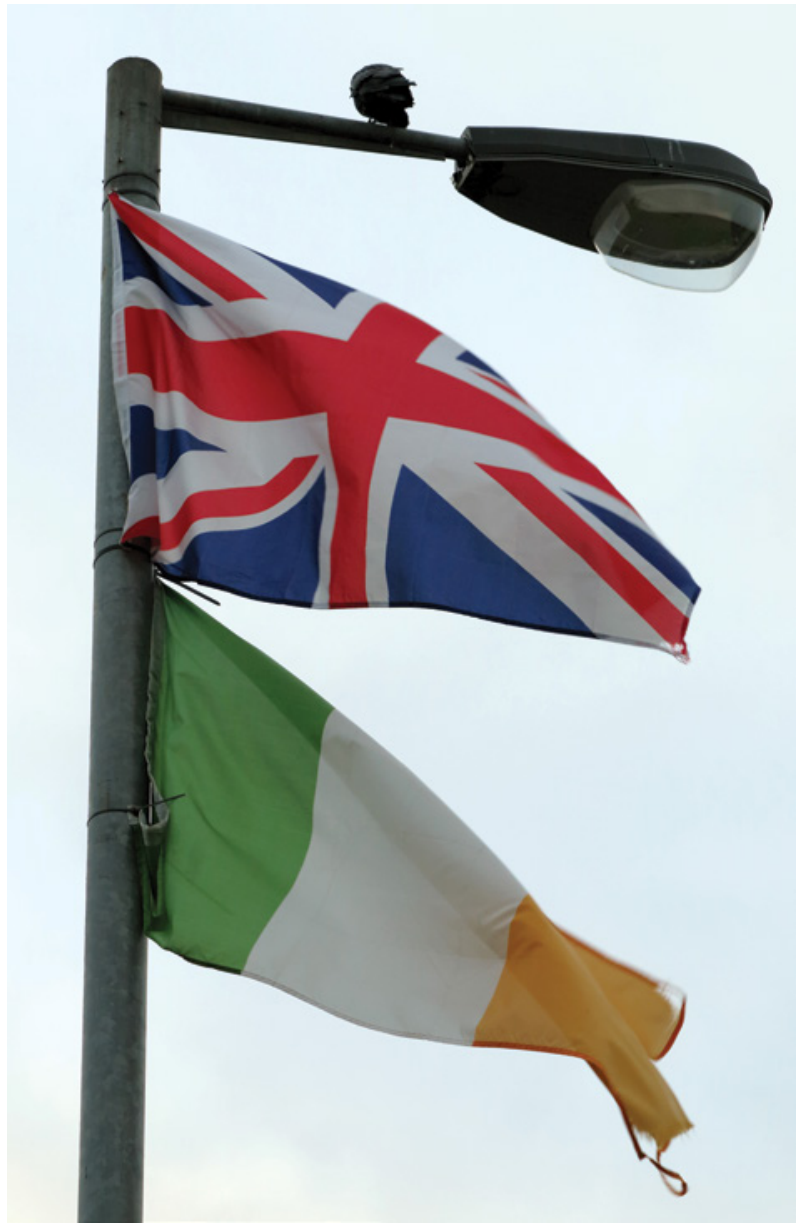

FIGURE 2 Union and Irish Tricolour flags on a lamppost (reflecting identity issues)

(C) CAIN (HTTP://CAIN.ULSTER.AC.UK/PHOTOGRAPHS)

that they are British (from $44 \%$ to $35 \%$ ) or Ulster (from $7 \%$ to $2 \%$ ). At the same time, there has been a very slight increase in the Irish identity (from $25 \%$ to $28 \%$ ) and Northern Irish (from $20 \%$ to $26 \%$ ).

Identity is also complex (see Figure 2; Curtice, Devine \& Ormston, 2013). Thus, on several occasions, the survey has included the 'Moreno question' (see Figure 3), which recognises dual and compound identities (Moreno, 2006). This reflects the Good Friday/Belfast Agreement, which recognises the right of people in Northern Ireland to identify themselves as Irish or British, or both. Respondents are asked to select which term best describes how they see 


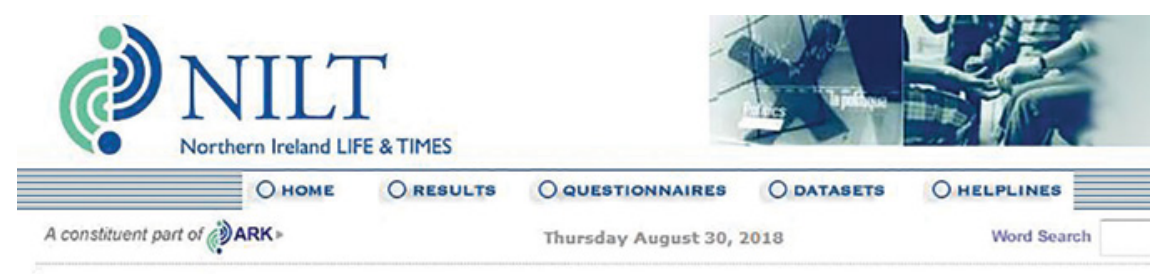

Year: 2017

Module: Political_Attitudes

Variable: IRBRIT

Some people think of themselves first as British. Others may think of themselves first as Irish. Which, if any, of the following best describes how you see yourself?

\begin{tabular}{|r|c|}
\hline Irish not British & \% \\
\hline More Irish than British & 10 \\
Equally Irish and British & 15 \\
More British than Irish & 18 \\
British not Irish & 23 \\
\hline Other description (WRITE IN) & 9 \\
Don't know & 1 \\
\hline
\end{tabular}

View Pie Chart Hide Pie Chart

Go to results for men and women, people of different religions, and people of different ages. Go to technical notes

FIGURE 3 Screen shot of 'Moreno' question on the NILT website

themselves: Irish not British/More Irish than British/Equally Irish and British/ More British than Irish/British not Irish/Other/Don't know.

Although it is a constituent part of the United Kingdom (UK), the range of political parties operating in Northern Ireland is very specific. The five main parties are Sinn Féin, Democratic Unionist Party (DUP), Social Democratic and Labour Party (SDLP), Ulster Unionist Party (UUP) and the Alliance Party. Smaller parties include the Green Party in Northern Ireland, and United Kingdom Independence Party (UKIP). The presence of other parties, such as the Conservative Party, Labour Party and Liberal Democrat Party is minimal.

One limitation of survey research, and especially when questions are asked face-to-face, is a tendency for respondents to under-report public support for controversial groups (Hayes \& McAllister, 2013, p. xi). For example, data from the early years of NILT indicated a considerable underestimation of support for Sinn Féin when compared with electoral results. Sinn Féin's perceived links to the IRA may have affected people's willingness to report their party affiliation in a face-to-face survey, due to social desirability bias. The IRA called a permanent ceasefire in 1997, followed by decommissioning of weapons in 
2005. Since then, Sinn Féin's electoral results have increased, as did people's reporting of affiliation in NILT.

\subsection{Tracking Change over Time}

Time series are important within NILT and so all questions are designed to be repeated in years to come. In particular, some modules (such as community relations and political attitudes) are asked every year. Furthermore, several of these questions had previously been asked in the Northern Ireland Social Attitudes Survey from 1989 to 1996 , thus extending the time series. For example, a question on perception of relations between Protestants and Catholics has been asked in every year of the NISA and NILT surveys. Figure 4 shows an upward trend, although with peaks and troughs reflecting political events. The optimism around the time of the 1994 paramilitary ceasefires and the signing of the 1998 Good Friday/Belfast Agreement are evident, as are deteriorating community relations around the flags dispute in 2012. In late 2012 and during 2013, there was much civil unrest following the vote by Belfast City Council to fly the Union flag over Belfast City Hall on 18 designated days, rather than every day (Robinson \& Devine, 2017). Of course, whilst the inclusion of time series questions has many benefits, the survey has also included new questions to reflect changes in the focus of public and social debates and policy.

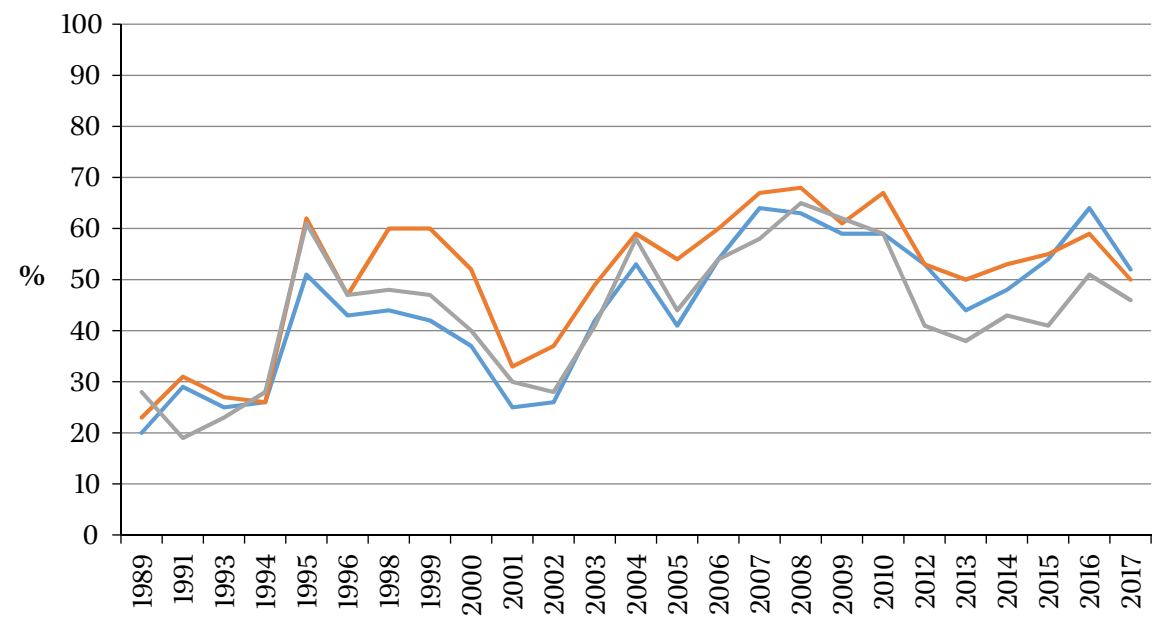

- Protestant Catholic - No religion

FIGURE 4 Graph showing respondents' perception of community relations over previous 5 years (\% of adults who think relations between Protestants and Catholics are better than they were five years ago, 1989 to 2017) NORTHERN IRELAND SOCIAL ATTITUDES SURVEY, 1989-1996; NORTHERN IRELAND LIFE AND TIMES SURVEY, 1998-2017 


\subsection{Accessibility}

From its inception, the underlying ethos of NILT was that the data and results should be freely available and accessible to everyone. Thus, tables of results for every question are made available on the survey website (www.ark.ac.uk/nilt) frequency tables, and crosstabulations by sex, six age groups (18-24, 25-34, 35-44, 45-54, 55-64 and 65+), and three religious affiliation categories (Protestant, Catholic and no religion). Given the nature of ethno-religious identity and conflict in Northern Ireland, it is appropriate to differentiate between 'Protestant' and 'Catholic'. This religious affiliation classification excludes respondents from other religions, due to the small number of people in this category. These key tables provide access to key findings for those users who do not have the time, skills or resources to undertake analysis themselves. However, by making the datasets widely available, researchers can undertake their own analysis.

The dataset for each year is made freely accessible in spss format on the survey website, along with the questionnaires and technical notes. The dataset and documentation are also deposited with the UK Data Service at https:// discover.ukdataservice.ac.uk/series/?sn=2000040. In order to maintain anonymity, several variables are excluded (for example, ethnicity), and other variables are recoded (for example, religion). The dataset provides information at a Northern Ireland level. The U K Data Service facilitates users to explore the NILT data and create their own tables, using the online Nesstar software. Whilst this is a very flexible tool, it requires users to have some understanding of datasets and data analysis.

\subsection{Teaching Datasets}

In order to provide a useful resource for the teaching of quantitative methods, seven teaching datasets have been created, each focusing on a particular topic (e.g., politics and good relations; ageing; LGBT issues). NILT is a public attitudes survey, and so the majority of questions are nominal or ordinal scale (for example, a Likert scale). In order to be useful for the teaching of quantitative methods, several ratio/continuous variables are created to enable a wider range of statistical testing to be undertaken. The teaching datasets are available on the NILT website, as well as being deposited with the UK Data Service.

\section{Funding}

There is no core funding for the survey. Instead, funding for NILT comes from a variety of sources, with each module within each year being funded by different sources, including the Economic and Social Research Council (ESRC), 
private philanthropic organisations, charitable bodies and government departments. These multiple funding sources mean that the survey can maintain its independence. However, such a complex funding mechanism is challenging, especially in periods of austerity. Nevertheless, the survey has run annually since 1998, with the only exception being 2011 when funding came through too late to run the survey.

\section{Impact}

NILT has become an essential resource for independent and statistically-robust attitudinal data. The data are used as statistical indicators for the evaluation of government policy, such as the Together: Building a United Community community relations strategy (OFMDFM, 2013), and the Racial Equality Strategy 2015-2025 (OFM DFM, 2015). Much academic work has taken advantage of the time series since 1998. Hayes and McAllister (2013) explored attitudes towards political change, whilst Tonge and Gomez (2015) focused on the growth of a Northern Irish identity. Comparative analysis includes the use of NILT and BSA data by Doebler and colleagues (2017) to look at negativity towards Muslims, Eastern Europeans and immigrants. While NILT's data on community relations and politics is used extensively, the survey also includes modules on wider social policy issues, such as dementia (McParland et al., 2012).

Since its inception, NILT has become recognised as an invaluable and respected source of information on the opinions of people living in Northern Ireland. One particular strength is its time series. However, its independence, policy relevance and representative sample have ensured that the survey has provided vital evidence for policy, academic and NGO communities over the past 20 years, and will continue to do so.

\section{Data}

- Northern Ireland Life and Times deposited at the UK Data Service - URL: https://discover.ukdataservice.ac.uk/series/?sn=2000040

- These datasets are also available from the survey website - URL: https:// www.ark.ac.uk/nilt

- Northern Ireland Life and Times Survey, 2014: 'Dementia' Teaching Dataset - DoI:http://doi.org/10.5255/UKDA-SN-8149-1

- Northern Ireland Life and Times Survey, 2014: 'Attitudes to Older People, Ageing and Ageism' Teaching Dataset - Dor:http://doi.org/10.5255/ UKDA-SN-8150-1 
- Northern Ireland Life and Times Survey, 2012: 'Lesbian, Gay, Bisexual and Transgender Issues' Teaching Dataset - Dor:http://doi.org/10.5255/ UKDA-SN-7546-1

- Northern Ireland Life and Times Survey, 2012: 'Politics and Good Relations' Teaching Dataset - DoI:http://doi.org/10.5255/UKDA-SN-7547-1

- Northern Ireland Life and Times Survey, 2008: 'Attitudes to Older People, Ageing and Ageism' Teaching Dataset - Dor:http://doi.org/10.5255/ UKDA-SN-8148-1

- Northern Ireland Life and Times Survey, 2008: 'Politics and Community Relations' Teaching Dataset - Dor:http://doi.org/10.5255/UKDASN-8147-1

- Northern Ireland Life and Times Survey, 2006: 'Politics and Community Relations' Teaching Dataset - Dor:http://doi.org/10.5255/UKDA-SN8146-1

- Temporal coverage: 1998-2016. Note that as NILT is an annual survey, datasets are added annually.

- Northern Ireland Social Attitudes deposited at the UK Data Service URL:https://discover.ukdataservice.ac.uk/series/?sn=2000041

- British Social Attitudes deposited at the UK Data Service - URL:https:// discover.ukdataservice.ac.uk/series/?sn=200006

- Continuous Household Survey deposited at the UK Data Service URL:https://discover.ukdataservice.ac.uk/series/?sn=200008

- Northern Ireland Attitude Survey deposited at the UK Data Service DoI:http://doi.org/10.5255/UKDA-SN-1347-1

The hyphenated number at the end of the Dor denotes a specific version of data released. All changes to data made are documented in the DOI change log, but older versions are not made routinely available.

\section{References}

Bechhofer, F., \& McCrone, D. (2010). Choosing National Identity. Sociological Research Online, 15. doi:https://doi.org/10.5153/sro.2191.

Curtice, J., Devine, P., \& Ormston, R. (2013). Devolution: Identities and constitutional preferences across the UK. In A. Park, C. Bryson, E. Clery, J. Curtice \& M. Phillips (Eds.), British Social Attitudes 3oth Report (pp. 139-172). London: NatCen.

Devine, P. (2018). Technical notes, Northern Ireland Life and Times Survey 2017. Belfast: ARK. 
Doebler, S., McAreavey, R. \& Shortall, S. (2017). Is racism the new sectarianism? Negativity towards immigrants and ethnic minorities in Northern Ireland from 2004 to 2015. Ethnic and Racial Studies, doi:https://doi.org/10.1080/01419870.2017.1392027.

Hayes, B. C., \& McAllister, I. (2013). Conflict to peace: Politics and society in Northern Ireland over half a century. Manchester: Manchester University Press.

McParland, P., Devine, P., Innes, A. \& Gayle, V. (2012). Dementia knowledge and attitudes of the general public in Northern Ireland: an analysis of national survey data. International Psychogeriatrics, 24:10, 1600-1613.

Moreno, L. (2006). Dual identities and stateless nations (the "Moreno question"). Scottish Affairs, 54, 1-21.

Moxon-Browne, E. (1983). Nation, Class and Creed in Northern Ireland. Aldershot: Gower.

Office of the First Minister and Deputy First Minister [ofmDfm] (2013). Together: Building a United Community. Belfast: OFMDFM.

Office of the First Minister and Deputy First Minister [OFMDFM] (2015). Racial Equality Strategy 2015-2025. Belfast: OFMDFM.

Robinson, G., \& Devine, P. (2017). Bonfires, Flags, Identity and Cultural Traditions. ARK Research Update 199. Belfast: ARK.

Rose, R. (1975). Northern Ireland Loyalty Study [Data file and codebook]. doi:https://doi. org/10.3886/ICPSR07237.v1.

Tonge, T. \& Gomez, R. (2015). Shared Identity and the End of Conflict? How Far Has a Common Sense of 'Northern Irishness' Replaced British or Irish Allegiances since the 1998 Good Friday Agreement?. Irish Political Studies, 30:2, 276-298. 